\title{
Effect of incorporation of grits waste on the densification behavior of soil-cement bricks
}

\section{(Efeito da incorporação de resíduo grits sobre o comportamento de densificação de tijolo solo-cimento)}

\author{
F. B. Siqueira, J.N.F. Holanda \\ Grupo de Materiais Cerâmicos, LAMAV-CCT, Universidade Estadual do Norte Fluminense Darcy Ribeiro \\ Av. Alberto Lamego 2000, Campos dos Goytacazes, RJ, Brazil 28013-602 \\ fabriciobagli@bol.com.br, jose.holanda@pesquisador.cnpq.br
}

\begin{abstract}
In the cellulose industry the Kraft process is widely used to produce cellulose. This process generates huge volumes of inorganic solid wastes, including the grits waste. In Brazil, the final disposal of this solid waste is of high economical and environmental interest. The present work assesses the influence of the addition of grits waste on the densification behavior of soil-cement bricks. The raw materials used were soil, Portland cement, and grits waste. Soil-cement bricks containing up to $30 \mathrm{wt} \%$ grits waste in partial replacement of Portland cement were prepared by uniaxial pressing and cured for 28 days. The following technological properties were determined: water absorption, compressive strength, and durability. The microstructure was evaluated by scanning electron microscopy and X-ray diffraction. The experimental results indicated that the addition of grits waste influenced positively the densification behavior of the soil-cement bricks. Moreover, the grits waste could be incorporated into the soil-cement brick composition up to $20 \mathrm{wt} . \%$ as a partial replacement of Portland cement.
\end{abstract}

Keywords:grits waste, soil-cement brick, densification, microstructure.

Resumo

O processo Kraft é o mais usado na indústria de celulose para produção de celulose. Este processo gera enormes volumes de resíduos sólidos inorgânicos, incluindo o resíduo grits. No Brasil, o descarte final deste resíduo sólido é de alto interesse econômico e ambiental. O presente trabalho avalia a influência da adição do resíduo grits sobre o comportamento de densificação do tijolo solo-cimento. As matérias-primas usadas foram solo, cimento portland e resíduo grits. Amostras de solo-cimento contendo até $30 \%$ em peso de resíduo grits, como substituto parcial de cimento Portland, foram preparadas por prensagem uniaxial e cura durante 28 dias. As seguintes propriedades tecnológicas foram determinadas: absorção de água, resistência à compressão simples e durabilidade. A microestrutura foi avaliada via microscopia eletrônica de varredura e difração de raios X. Os resultados experimentais indicaram que a incorporação do resíduo grits influenciou positivamente o comportamento de densificação do tijolo solo-cimento. Além do mais, o resíduo grits poderia ser incorporado até $20 \%$ em peso como substituto de cimento Portland na composição do tijolo solo-cimento.

Palavras-chave: resíduo grits, tijolo solo-cimento, densificação, microestrutura.

\section{INTRODUCTION}

Brazil is ranked as one of the major cellulose producer worldwide. In 2013, Brazil produced about 15.1 million tones of cellulose [1]. The Kraft process is the most used technological route in the cellulose production. In the Kraft process different types of inorganic solid wastes are produced, including the grits waste derived from the causticization step of the liquor [2]. The grits waste is rich in calcite $\left(\mathrm{CaCO}_{3}\right)$ [3]. From an environmental point of view, it is classified as non-inert (class IIA) according with Brazilian regulations $[3,4]$. In 2013, Brazil produced about 365 thousand tonnes of grits waste [1]. On the other hand, the high volume of grits waste produced cannot simply be discarded in the environment without appropriate treatment. For this reason, it is necessary to find viable alternative technologies for the final disposal of this solid waste material. Different alternative methods for the final disposal of grits waste from the cellulose industry were tested, including agriculture, road paving, red ceramic, and cement clinker production [58]. The reuse of grits waste for production of soil-cement bricks has been also suggested [3, 4, 9]. However, the densification behavior of soil-cement bricks containing grits waste is still to be investigated. The soil-cement brick is an attractive building material because of its low cost [10]. In fact, the production process of soil-cement bricks eliminates the firing step with high energy consumption. The soilcement brick corresponds to a hardened material formed by pressing and curing of a homogeneous intimate mixture of soil, Portland cement, and water in appropriate proportions $[10,11]$. In particular, it is recommended a ratio of soil and Portland cement with less Portland cement consumption 
associated with suitable technical properties. After the curing process, the soil-cement bricks must meet the specifications in terms of technical properties such as water absorption, compressive strength, durability, and volumetric shrinkage.

The aim of this work is to evaluate the influence of the incorporation of grits waste as a partialreplacement of Portland cement on the densification behavior of soilcement brick.

\section{MATERIALS AND METHODS}

Four paste of soil-cement mixture containing up to 30 wt.\% grits waste were prepared. In this work, the Portland cement was partially replaced with grits waste. Each paste (soil:cement:waste) is labeled as follows: TFR - 9:1:0 reference soil-cement paste, TF1 - 9:0.9:0.1, TF2 -9:0.8:0.2, and TF3 - 9:0.7:0.3. The soil sample collected in a local ceramic industry located in Campos dos Goytacazes, RJ, was dried at $110^{\circ} \mathrm{C}$, and then sieved until a fraction passing through a 4 mesh (4.75 mm ASTM) sieve. The grits waste sample was colleted in a cellulose industry located in Aracruz-ES. The waste sample was dried at $110^{\circ} \mathrm{C}$ for $48 \mathrm{~h}$ in an oven. It was crushed in a ball milling, and then sieved until a fraction passing through a 200 mesh $(<75 \mu \mathrm{m}$ ASTM $)$ sieve. Commercial Portland cement (CP III-40RS) was used.

The chemical compositions of the raw materials were determined by using an energy-dispersive X-ray spectrometer (Shimadzu, EDX 700). The loss on ignition was determined according to $\mathrm{LOI}=(\mathrm{Md}-\mathrm{Mc}) / \mathrm{Md} \times 100$, in which $\mathrm{Md}$ is the weight of the sample dried at $110^{\circ} \mathrm{C}$ and $\mathrm{Mc}$ is the weight of the sample calcined at $1000{ }^{\circ} \mathrm{C}$ for $2 \mathrm{~h}$. X-ray diffraction analysis of the raw materials was done in a conventional diffractometer (Shimadzu, XRD 7000 diffractometer) using monochromatic $\mathrm{Cu}-\mathrm{K} \alpha$ radiation, angular range $8^{\circ} \leq 2 \theta \leq 70^{\circ}$, and scanning rate $1.5^{\circ}(2 \theta / \mathrm{min})$. The particle size distribution of the soil sample was determined by a combination of sieving and sedimentation procedures according to the NBR 7181 standard. The plasticity of the soil was determined by the Atterberg method according to the NBR 6459 and NBR 7180 standards. The fineness index of the Portland cement and grits waste was determined according to the NBR 9202 standard. The pozzolanic activity of the grits waste sample was assessed according to the NBR 5752 standard.

The soil/cement/grits waste pastes were homogenized in a laboratory mixer during $15 \mathrm{~min}$, and then humidified with water at $16 \mathrm{wt} . \%$ of the total weight. Cylindrical soil-cement bricks $(\phi 37 \mathrm{~mm})$ were prepared by single action pressing at $18 \mathrm{MPa}$, and then cured for 28 days in a humid chamber (95\% humidity at $23^{\circ} \mathrm{C}$ ).

The following technological properties have been determined in the cured soil-cement bricks using standardized procedures: water absorption, compressive strength, and durability. Scanning electron microscopy (Shimadzu, SSX- 550) operating at $15 \mathrm{kV}$ was used to examine the gold-coated fracture surface of the cured bricks. The mineralogical analysis of the soil-cement bricks after 28 days of curing was done with X-ray diffraction.

\section{RESULTS AND DISCUSSION}

The mineral phases of the raw materials identified via $\mathrm{X}$-ray diffraction are presented in Table I. The soil sample is mainly composed of kaolinite and quartz, and minor amounts ofillite/mica, gibbsite, and goethite. This is in accordance with the literature [12]. In fact, the soil was collected in a local ceramic industry as a "weak" clay rich in kaolinite and free quartz (sand). The grits waste was essentially composed of calcium-based materials (calcite, personite, and portlandite), mainly of calcite $\left(\mathrm{CaCO}_{3}\right)$. As expected, the following mineral phases in the Portland cement (CP III-40RS) were identified: tricalcium aluminate $\left(\mathrm{C}_{3} \mathrm{~A}\right)$, tetracalcium aluminoferrite $\left(\mathrm{C}_{4} \mathrm{AF}\right)$, belite $\left(\mathrm{C}_{2} \mathrm{~S}\right)$, alite $\left(\mathrm{C}_{3} \mathrm{~S}\right)$, and gypsum.

Table I - Mineral phases identified in the raw materials.

[Tabela I - Fases minerais identificadas nas matériasprimas.]

\begin{tabular}{lccc}
\hline Minerals & Soil & Cement & $\begin{array}{c}\text { Grits } \\
\text { waste }\end{array}$ \\
\hline Kaolinite & & & \\
Quartz & & & \\
Illite/mica & & & \\
Gibbsite & $\mathrm{X}$ & & \\
Goethite & $\mathrm{X}$ & & \\
Tricalcium aluminate & $\mathrm{X}$ & $\mathrm{X}$ & \\
Tetracalcium aluminoferrite & $\mathrm{X}$ & $\mathrm{X}$ & \\
Belite & $\mathrm{X}$ & $\mathrm{X}$ & \\
Alite & & $\mathrm{X}$ & $\mathrm{X}$ \\
Gypsum & & $\mathrm{X}$ & $\mathrm{X}$ \\
Calcite & & & $\mathrm{X}$ \\
Portlandite & & & \\
Personite & & & \\
\hline
\end{tabular}

The chemical compositions of the raw materials, as well as their loss on ignition, are given in Table II. The results are consistent with the X-ray diffraction data (Table I). It was verified that the soil sample is rich in silica $\left(\mathrm{SiO}_{2}\right)$ typically of sandy soil. The grits waste sample is rich in calcium oxide $(\mathrm{CaO})$. The high loss on ignition $(29.10 \mathrm{wt} . \%)$ is mainly attributed to the decomposition of calcite to calcium oxide and carbon dioxide $\left(\mathrm{CaCO}_{3} \rightarrow \mathrm{CaO}+\uparrow \mathrm{CO}_{2}\right)$. The results also showed that there are differences between the chemical compositions of the grits waste and Portland cement. The grits waste has higher calcium oxide content and higher loss on ignition. Thus, the incorporation of grits waste into a conventional soil-cement brick paste modifies its chemical and mineralogical composition.

The particle size distribution of the soil sample is shown in Fig. 1. The soil sample presented a wide range of particles sizes, whose $\mathrm{D}_{50}$ is about $75 \mu \mathrm{m}$. The soil sample had $100 \%$ of the particles passing in a 4 mesh ( $4.75 \mathrm{~mm}$ ASTM) sieve. It has 22.4 wt. $\%$ clay $(<2 \mu \mathrm{m}), 28.4$ wt. $\%$ silt $(2 \leq x<63$ $\mu \mathrm{m})$, and $49.2 \mathrm{wt} . \%$ sand $(>63 \mu \mathrm{m})$. This result indicates that the soil sample selected meets granulometric behavior very 
close to that suggested by the ABCP [11] for soil-cement mixes. In terms of plasticity, the soil sample presented the following values: liquid limit $=27.8 \%$, plastic limit $=$ $18.4 \%$, and plastic index $=9.5 \%$. Thus, the soil sample used also meets the plasticity requirements set by $\mathrm{ABCP}$ [11].

Table II - Chemical composition of the raw materials (wt.\%). [Tabela II - Composição química das matérias-primas $(\%$ peso)]

\begin{tabular}{lccc}
\hline \multicolumn{1}{c}{ Components } & Soil & Cement & Grits waste \\
\hline $\mathrm{SiO}_{2}$ & 46.70 & 18.87 & - \\
$\mathrm{Al}_{2} \mathrm{O}_{3}$ & 28.63 & 7.11 & - \\
$\mathrm{CaO}$ & 0.98 & 65.15 & 68.67 \\
$\mathrm{Fe}_{2} \mathrm{O}_{3}$ & 7.40 & 1.21 & - \\
$\mathrm{K}_{2} \mathrm{O}$ & 3.80 & 0.56 & 1.04 \\
$\mathrm{SO}_{3}$ & 2.00 & 3.71 & 1.04 \\
$\mathrm{TiO}_{2}$ & 2.21 & 0.53 & - \\
$\mathrm{ZrO}_{2}$ & 0.24 & - & 0.01 \\
$\mathrm{~V}_{2} \mathrm{O}_{5}$ & 0.13 & - & - \\
$\mathrm{MnO}$ & 0.07 & 0.30 & - \\
$\mathrm{ZnO}$ & 0.02 & - & - \\
$\mathrm{SrO}$ & 0.01 & 0.06 & 0.16 \\
$\mathrm{Y}_{2} \mathrm{O}_{3}$ & 0.01 & - & - \\
Loss on ignition & 7.80 & 2.50 & 29.08 \\
\hline
\end{tabular}

The fineness index of the Portland cement and grits waste is given in Table III. The value of the fineness index of the Portland cement was found to be lower than that of the grits waste. This difference of fineness index is important because it could encourage a more efficient packing of soil-cement-waste mixtures.

The densification behavior of the soil-cement bricks after curing for 28 days, which is the usual curing time adopted in the industrial processing, was determined on the basis of technical properties, microstructure, and X-ray diffraction analysis.

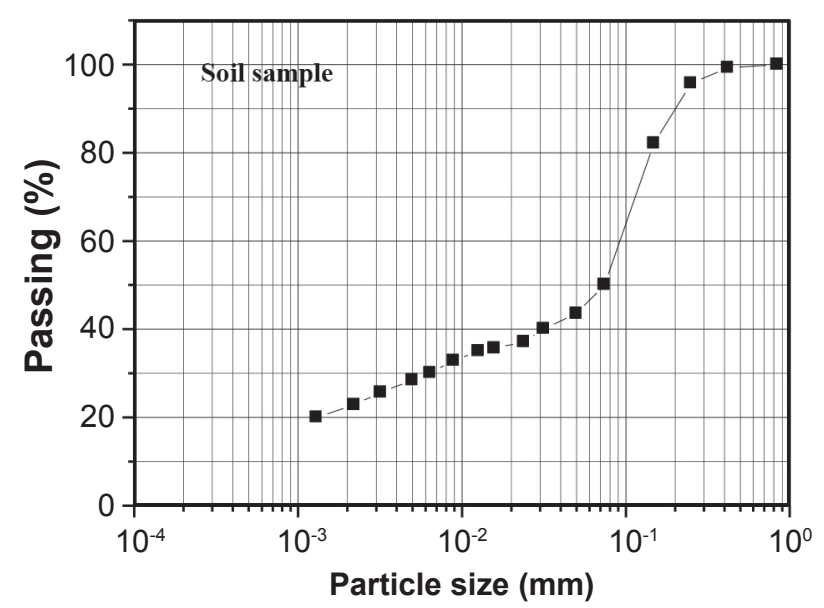

Figure 1: Particle size distribution of the soil sample.

[Figura 1: Distribuição de tamanho de partícula da amostra do solo.]
Table III - Results of fineness index of the Portland cement and grits waste.

[Tabela III - Resultados do índice de finura do cimento Portland e resíduo grits.]

\begin{tabular}{ccc}
\hline \multirow{2}{*}{$\begin{array}{c}\text { Sieve } \\
\text { (mesh) }\end{array}$} & \multicolumn{2}{c}{ Sieve residue (wt.\%) } \\
\cline { 2 - 3 } & Portland cement & Grits waste \\
\hline 200 & 0.00 & 0.00 \\
250 & 0.21 & 0.73 \\
270 & 0.15 & 0.71 \\
325 & 0.84 & 4.36 \\
\hline
\end{tabular}

Fig. 2 shows the X-ray diffractograms of the soil-cement bricks incorporated with grits waste after curing for 28 days. As expected, the mineralogical analysis of the reference soil-cement paste (TFR sample) presented the following phases: i) mineral phases linked with the soil: kaolinite, quartz, goethite, and gibbsite; and ii) mineral phases linked with the hydration of the Portland cement: calcium silicate hydrate, ettringite, and portlandite. For the grits waste containing traces, the calcite was also identified. This is due to the grits waste to be composed mainly of calcite. It can be also observed that the introduction of grits waste has caused small changes in the intensities of the diffraction peaks. Thus, the incorporation of grits waste tends to modify the mineralogical behavior of the traditional soil-cement paste.

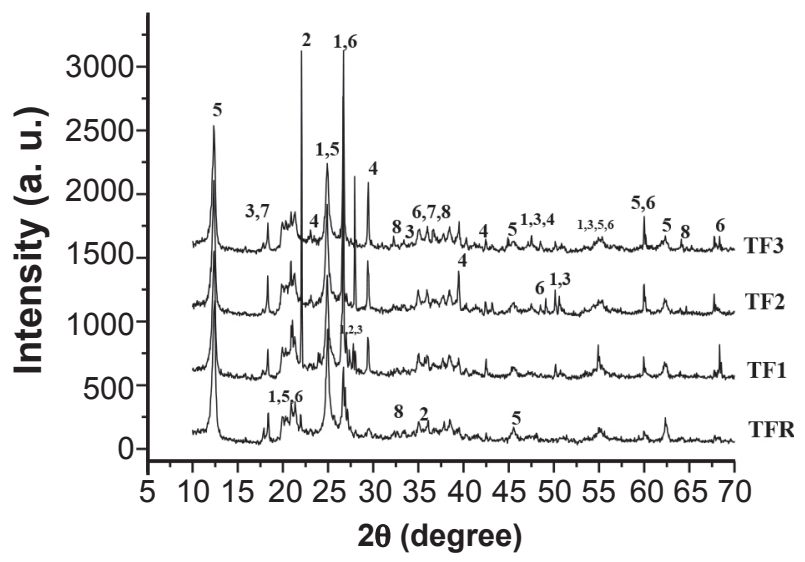

Figure 2: XRD patterns for the soil-cement bricks after curing for 28 days. 1: calcium silicate hydrate; 2 : ettringite; 3 : portlandite; 4: calcite; 5: kaolinite; 6: quartz; 7: gibbsite; and 8: goethite.

[Figura 2: Difratogramas de raios $X$ dos tijolos solo-cimento. 1: silicato de cálcio hidratado; 2: etringita; 3 : portlandita; 4: calcita; 5: caulinita; 6: quartzo; 7: gibsita; e 8: goetita.]

Fig. 3 shows the fracture surfacesobtained via secondary electron images of the grits waste containing soil-cement bricks after curing for 28 days. SEM micrographs show the typical sequence of densification with rising amounts of grits waste. It can be seen the distribution of the particles of soil, grits waste, and the hydrated cement paste composed of calcium silicate hydrate, ettringite, and portlandite (Fig. 2). The TFR sample (Fig. 3a) presented a fracture surface 

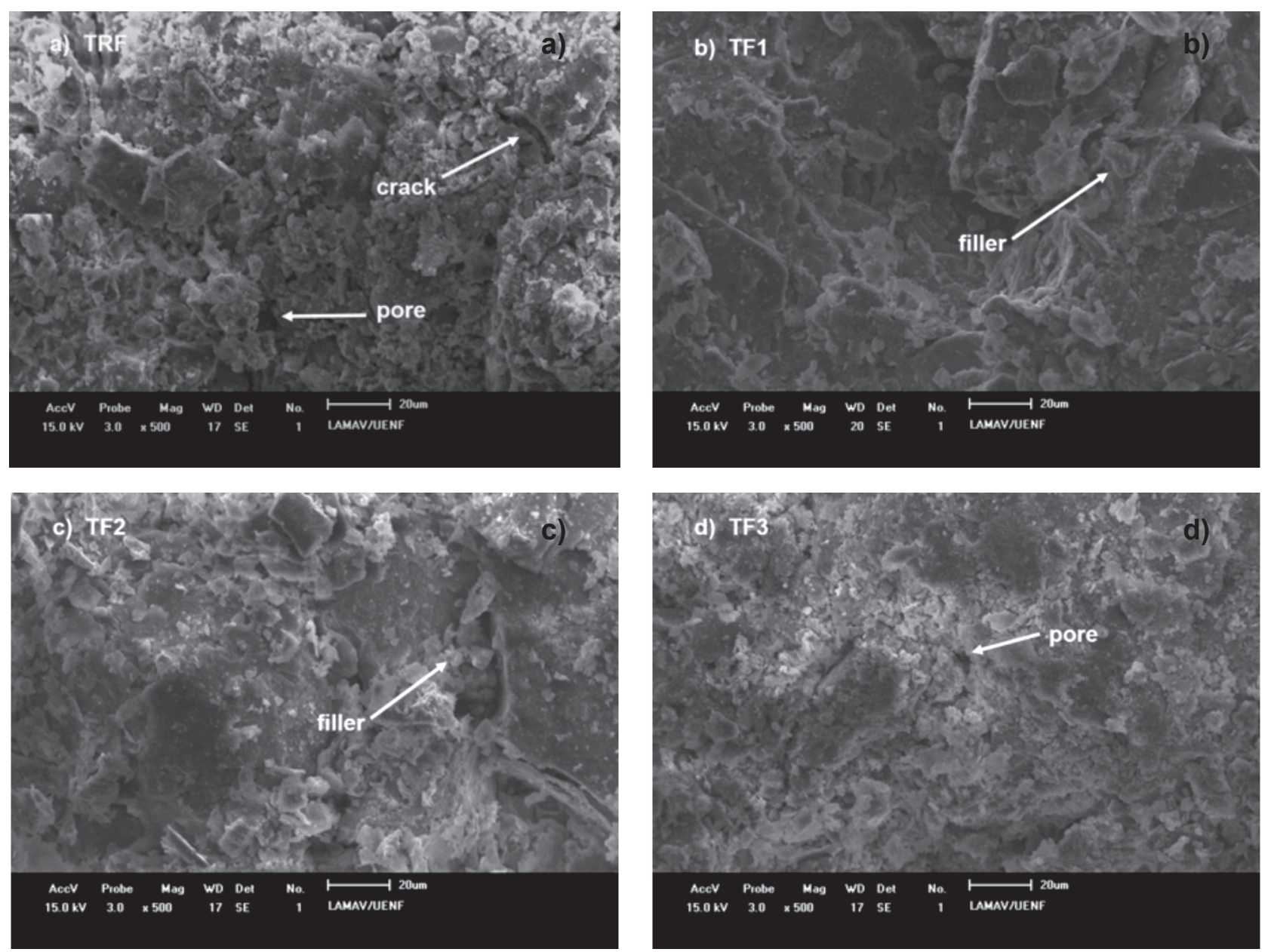

Figure 3: SEM micrographs of the fracture surface of the cured soil-cement bricks: a) TFR; b) TF1; c) TF2; and d) TF3.

[Figura 3: Micrografias obtidas por MEV da superfície de fratura dos tijolos solo-cimento curados: a) TFR; b) TF1; c) TF2; e d) TF3.]

with rough texture and presence of capillary porous. This is a typical microstructure of conventional soil-cement trace. For additions up to 20 wt.\% of grits waste (Fig. 3b-c), a denser microstructure was observed. The filler effect of the grits waste is responsible for the higher densification of the soil-cement-waste mixture. The TF3 sample (Fig. 3d), however, presented a more porous fracture surface. In this case, the grits waste was less efficient in the densification of the soil-cement-waste mix. Furthermore, the lesser amount of Portland cement in the TF3 sample certainly contributed to negatively influence the soil stabilization. Line spectrum for the soil-cement bricks determined using EDS/SEM is shown in Fig. 4. It can be seen that thespectrum lines are very similar, and are consistent with the chemical composition data (Table II).

Table IV shows the technological properties of the soilcement bricks after curing for 28 days. The analysis of results indicates that the partial replacement of Portland cement with grits waste influenced positively the densification behavior of the soil-cement bricks. The incorporation of grits waste also influenced positively the compressive strength of soil-cement brick. The 28-days compressive strength of soil-cement bricks containing grits waste is up to $15 \%$ higher than that of reference soil-cement trace (TFR sample). It was found that all soil-cement brick pastes met compressive strength prescribed by the Brazilian standard NBR 10834 (mean compressive strength $\geq 2.0 \mathrm{MPa}$ and individual compressive strength $\geq 1.7 \mathrm{MPa}$ ) [13]. The water absorption that is related to the open porosity level was found to decrease, as the Portland cement was replaced with up to $20 \mathrm{wt} . \%$ of grits waste. This effect of enhancing the packing and densification of the soil-cement mixture is related to the grits waste, which is composed in majority of calcite particles. In this case the grits waste acts as a filler material, and positively provided a reduction of the open porosity level of the soil-cement mixture. In addition, the grits waste has low chemical activity as cementitious material, i.e., it is a non-pozollanic material. In fact, the grits waste presented a pozzolanic index of $49.1 \%$, which is below the value prescribed by the NBR 12653 standard (> 75\%) [14]. For additions above $20 \mathrm{wt} . \%$ grits waste, the filler effect of the grits waste is less effective and an increase in water absorption occurred. This is in accordance with the microstructure (Fig. 3). The requirements of water absorption for soil-cement bricks according to Brazilian standard NBR 10834 [13] are: mean water absorption $\geq$ $20 \%$ and individual water absorption $<22 \%$. The results of Table IV show that the water absorption specification was 


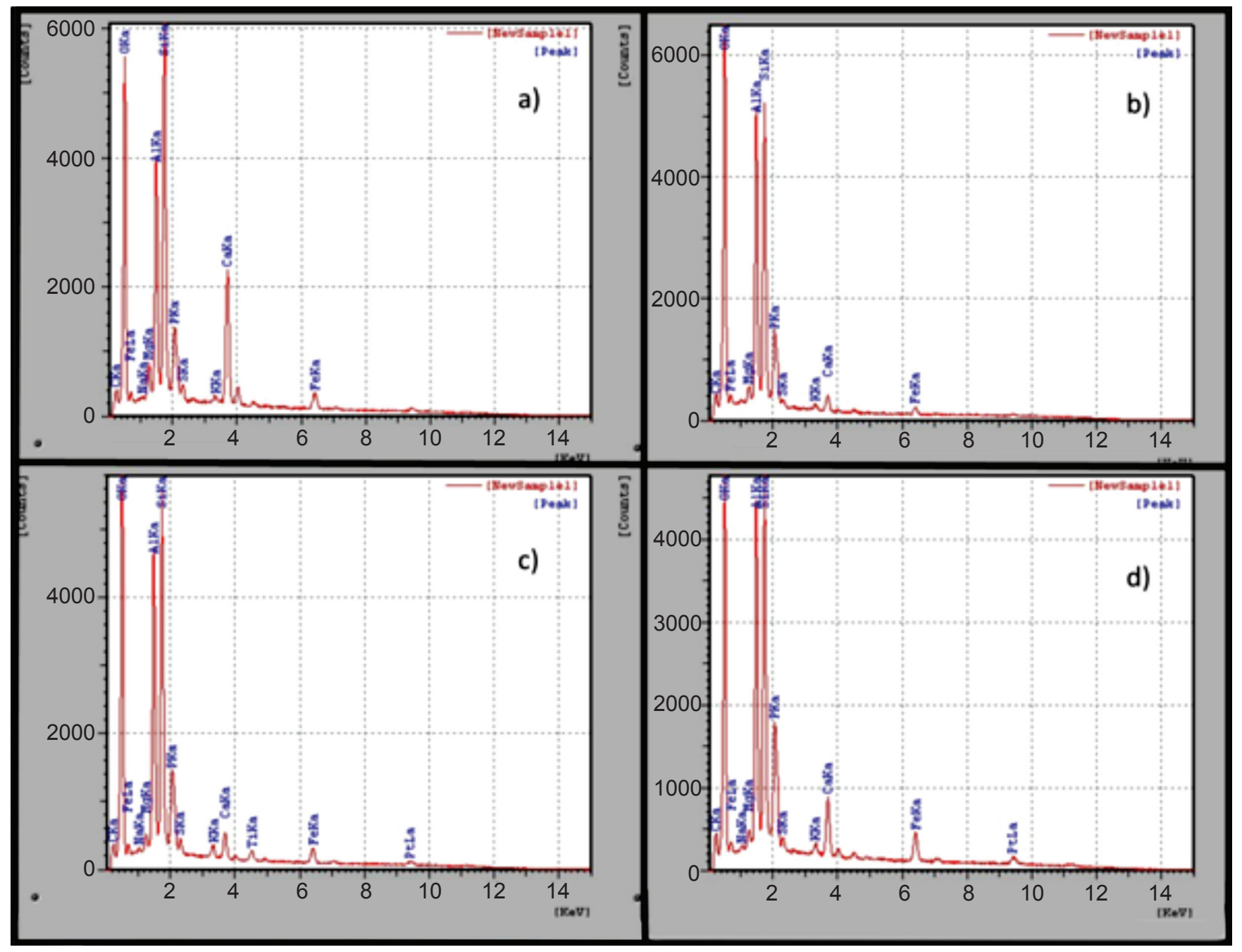

Figure 4: Line spectrum/EDS for the cured soil-cement bricks: a) TFR; b) TF1; c) TF2; and d) TF3. [Figura 4: Espectro EDS para os tijolos solo-cimento curados: a) TFR; b) TF1; c) TF2; e d) TF3]

Table IV - Technological properties of the soil-cement bricks.

[Tabela IV - Propriedades tecnológicas dos tijolos solocimento.].

\begin{tabular}{cccc}
\hline Trace & $\begin{array}{c}\text { Compressive } \\
\text { strength } \\
(\mathrm{MPa})\end{array}$ & $\begin{array}{c}\text { Water } \\
\text { absorption } \\
(\%)\end{array}$ & $\begin{array}{c}\text { Mass } \\
\text { loss } \\
(\%)\end{array}$ \\
\hline TFR & 5.13 & 20.40 & 11.85 \\
TF1 & 5.89 & 18.02 & 7.27 \\
TF2 & 5.55 & 17.56 & 6.48 \\
TF3 & 5.62 & 21.68 & 18.29 \\
Brazilian & $\geq 2.00 *$ & $<20.00 *$ & $<10.00 * *$ \\
Standard & & & \\
\hline${ }^{*}$ NBR 10834 **NBR 13554 & &
\end{tabular}

obtained with incorporation of up to $20 \mathrm{wt} . \%$ of grits waste. This means that the physical stabilization of the soil-cement mixture can be made with the controlled addition of grits waste.

The results of durability of the soil-cement bricks determined by the mass loss are also presented in Table IV. As can be seen, the mass loss presented different behavior with grits waste addition. For additions up to $20 \mathrm{wt} \%$ grits waste, the mass loss of the soil-cement bricks decreased. In additions above $20 \mathrm{wt} \%$ grits waste, however, the mass loss increased. These results are justified by the micro-filler action of the grits waste, and are in accordance with the water absorption and microstructure. The requirement of durability for soil-cement bricks according to the Brazilian standard NBR 13553 [15] is a mass loss $<10 \%$. Thus, the results of Table IV suggest that additions of up to $20 \mathrm{wt} \%$ grits waste could be used in soil-cement brick pastes. This result is very interesting from both economical and environmental point of view, since it favors the reduction of Portland cement consumption in the production of soil-cement bricks.

\section{CONCLUSIONS}

The grits waste from the cellulose industry could be used as an alternative inexpensive raw material as a partial replacement of up to $20 \mathrm{wt} \%$ of Portland cement in the 
manufacture of soil-cement bricks. It was demonstrated that the grits waste and Portland cement presented different physical, chemical, and mineralogical characteristics. The incorporation of grits waste caused important changes in the technological properties (water absorption, compressive strength, and durability) and microstructure of the soilcement bricks. The grits waste is a non-pozzolanic material rich in calcite particles, which acts as a micro-filler material; when added in moderate amounts (up to $20 \mathrm{wt} . \%$ ) as a Portland cement replacement, it influences positively the packing and densification of soil-cement brick paste.

\section{ACKNOWLEDGEMENTS}

To CNPq and CAPES for financial support. Authors also would like to thank Fibria Celulose for the supply of grits waste.

\section{REFERENCES}

[1] Bracelpa, http;//www.bracelpa.org.br, acessado em 09/09/2014.

[2] R.M.V. Assunção, M.R.R. Pinho, R. Cahen, D. Phlipp, Celulose e Papel: Tecnologia de Fabricação da Pasta Celulósica, 2a Ed., IPT, S. Paulo, SP (1988).

[3] F.B. Siqueira, J.N.F. Holanda, J. Environ. Manag. 131 (2013) 1-6.

[4] M.L. Pinheiro, R.C.S.S. Alvarenga, B.C. Pinheiro, P.S. Silva Júnior, M.S. Sarmet, D.P. Fassoni, Ambiente Construído 13, 2 (2013) 29-46.
[5] I. Demir, M.S. Baspinar, M. Orhan, Build. Environ. 40 (2005) 1533-1537.

[6] F. Castro, C. Vilarinho, D. Trancoso, P. Ferreira, F. Nunes, A. Miragaia, Int. J. Mater. Eng. Innov. 1, 1 (2009) 74-90.

[7] R. Modolo, A. Bento, V.M. Ferreira, L.M. Machado, Waste Manag. 30, 4 (2010) 685-696.

[8] C.C. Machado, C.R.M. Portugal, Rev. Árvore 36, 3 (2012) 519-526.

[9] L.A. Miranda, P.C.M.P. Junior, R.C.S.S. Alvarenga, A.G.S. Carvalho, C.A.B. Carvalho, D.P. Fassoni, Anais ELECS 2009, Recife, PE, Brazil (2009).

[10] A.A. Segantini, P. H. Wada, Acta Scient. Technol.33, 2 (2011) 179-183.

[11] Associação Brasileira de Cimento Portland - ABCP, Fabricação de tijolos e blocos de solo-cimento com utilização de prensas manuais, Boletim Técnico BT 111, S. Paulo, SP(1985) in Portuguese.

[12] S.J.G. Sousa, J.N.F. Holanda, Cerâmica 58, 345 (2012) 29-35.

[13] Associação Brasileira de Normas Técnicas - ABNT, Materiais pozolânicos, NBR 12653, Rio de Janeiro, RJ (1992).

[14] Associação Brasileira de Normas Técnicas - ABNT, Fabricação de tijolo maciço de solo-cimento com a utilização de prensa manual, NBR 10832, Rio de Janeiro, RJ (1992).

[15] Associação Brasileira de Normas Técnicas - ABNT, Solo-cimento: ensaio de durabilidade por molhagem $e$ secagem, NBR 13554, Rio de Janeiro, RJ (1996).

(Rec. 20/03/2015, Ac. 02/07/2015) 